\title{
PENGARUH PRAKTIK MANAJEMEN SUMBER DAYA MANUSIA TERHADAP KINERJA KARYAWAN DI PT. INDO-RAMA SYNTHETICS Tbk. DIVISI SPUN YARNS
}

\author{
Sarif Hidayat. SE., MM'1), \\ ${ }^{1}$ Sekolah Tinggi Ilmu Ekonomi Dr Khez Muttaqien - Program Studi Akuntansi \\ email: sarifhidayat@gmail.com
}

\begin{abstract}
This study aims to determine the impact of the integration of the management system ISO 9001: 2008 is used as a variable X1 on the quality of human resources, ISO 14001: 2004 is used as a variable X2 on the working environment, OHSAS 18001: 2007 is used as a variable X3 about the health and safety to the quality of human resources.

This study uses explanatory research and hypothesis testing, with survey technique, distributing questionnaires with Likert scale. Sampling technique with probability sampling, are used slovin formula and obtained a sample of 94 respondents.

Data analysis used descriptive analysis and inferential analysis, namely: (1) The validity and reliability, (2) Multiple Regression Analysis, (3) analysis of partial correlation coefficients, (4) Multiple Correlation Analysis, (5) The coefficient of determination, (4) Hypothesis Testing and partial test ( $t$ test) and a simultaneous test ( $F$ test).
\end{abstract}

The test results and analysis as follows:

1. There is a positive and significant effect between the competence of the quality of human resources with a positive correlation 0.522. competence contribution to the Quality of human resources amounted to $27.22 \%$, with a $t_{\text {hitung }}$ value of 5.87 with a significance $t_{\text {table }} 1.986$.

2. There is a positive influence and significant between the working environment of the employees with positive correlation 0.597. Environmental work contribute to the quality of human resources of $35.6 \%$, with a value of $7.14 t_{\text {hitung }}$ of the significance $t_{\text {table }}$ of 1.986 .

3. There is a positive and significant influence between $K 3$ to the Quality of human resources with a positive correlation for 0.451. The occupational safety and health contributes to quality of human resources is $20.3 \%$, with a value of 4.85 with a significant $t_{\text {hitung }} t t_{\text {table }} 1.986$.

4. The strong relationship between variables simultaneously X1, X2, and X3 to Y by 0.628, the contribution of all independent variables on the dependent variable simultaneously by $39.4 \%$, $F_{\text {hitung }} 19.5$ with signifkansi $F_{\text {tabel }} 1.39$.

Keywords: ISO 9001, ISO 14001, OHSAS \& COMPETENCE 


\section{PENDAHULUAN}

Krisis ekonomi yang terjadi akhir-akhir ini membawa dampak sangat besar pada dunia bisnis Indonesia. Maraknya krisis pemutusan hubungan kerja baik secara sukarela atau sepihak menunjukkan bahwa SDM (sumber daya manusia) masih dianggap sebagai salah satu faktor produksi dan bukan sebagai aset perusahaan yang berarti mitra kerja perusahaan.

Setiap organisasi perusahaan beroperasi dengan menggunakan seluruh sumber dayanya untuk dapat menghasilkan produk baik barang/jasa yang bisa dipasarkan. Dalam hal ini pengelolaan sumber daya yang dimiliki perusahaan meliputi sumber daya finansial, fisik, SDM, dan kemampuan teknologis dan sistem (Simamora, 1995). Karena sumbersumber yang dimiliki perusahaan bersifat terbatas sehingga perusahaan dituntut mampu memberdayakan dan mengoptimalkan penggunaannya untuk mempertahankan kelangsungan hidup perusahaan.

Dari berbagai sumber daya yang dimiliki perusahaan SDM menempati posisi strategis diantara sumber daya lainnya. Tanpa SDM, sumber daya yang lain tidak bisa dimanfaatkan apalagi dikelola untuk menghasilkan suatu produk. Tetapi dalam kenyataanya masih banyak perusahaan tidak menyadari pentingnya SDM bagi kelangsungan hidup perusahaan. Masih banyak perusahaan yang menganggap SDM adalah aset organisasi yang paling penting, karena SDM yang menggerakkan dan membuat sumber daya lainnya bekerja.

SDM merupakan asset kritis organisasi yang tidak hanya diikutsertakan dalam filosofi perusahaan tetapi juga dalam proses perencanaan strategis. Menurut Kathrin Connor (dikutip dari Schuller, 1990), wakil presiden SDM di Liz Claiborne:

Human resources are a part of the strategic planning process. It is a part of policy development, line extension planning and the merger and acquisition processes. Little is done in planning policy on the finalization stages of any deal.

Masalah-masalah SDM terus meningkat khususnya berkenaan dengan supply tenaga kerja terampil, yang memiliki kemampuan adaptasi memadai, dan mampu menghadapi kerancuankerancuan yang ada (ambiguitas). SDM mempunyai andil yang besar bagi keberhasilan bisnis. Isu-isu SDM meliputi isu bisnis yang berkaitan dengan tenaga kerja, dan isu-isu tersebut mempengaruhi esensi bisnis seperti profitabilitas, survival, daya saing, kemampuan adaptasi dan fleksibilitas.

Kritisnya peran SDM tidak disertai dengan sifat kepastian tenaga kerja. Justru sebaliknya terdapat peningkatan ketidakpastian tenaga kerja yang dihadapi organisasi. Organisasi tidak dapat menentukan secara pasti hal-hal yang berkenaan dengan supply tenaga kerja antara lain :1) Bagaimana menarik, mempertahankan, dan memotivasi SDM yang semakin beragam 2) Bagaimana cara mendapatkan individu yang memiliki keterampilan, pengetahuan, dan kemampuan yang tepat. Akhirnya bagaimana mengarahkan SDM yang ada agar dapat menjadi sumber keunggulan kompetitif baik secara domestik maupun internasional.

Di PT. Indo-Rama Synthetics Tbk. Divisi Spun Yarns, praktik-praktik manajemen sumber daya manusia disetiap aktivitas pada dasarnya banyak yang sudah dilakukan diantaranya mengenai praktik-praktik manajemen seperti pelaksanaan kompensasi, pengembangan karir, dan pelatihan sumber daya manusia telah diimplementasikan, selanjutnya bagaimana peran karyawan dalam mengaplikasikannya dalam kaitannya dengan kinerja mereka.

Berdasarkan beberapa masalah tersebut, maka peneliti ingin membahas mengenai pelaksanaan praktik-praktik manajemen sumber daya manusia khususnya mengenai pelaksanaan kompensasi, pengembangan karir, dan 
pelatihan sumber daya manusia dan dampaknya terhadap kinerja karyawan di PT. Indo-Rama Synthetics Tbk Divisi Spun Yarns.

\section{RUMUSAN MASALAH}

1 .

agaimana pengaruh pelaksanaan kompensasi/imbalan terhadap kinerja karyawan pada PT. Indo-Rama Synthetics Tbk. Divisi Spun Yarns?

2. Bagaimana pengaruh pengembangan karir terhadap kinerja karyawan pada PT. Indo-Rama Synthetics Tbk. Divisi Spun Yarns?

1. Bagaimana pengaruh pelatihan sumber daya manusia terhadap kinerja karyawan pada PT. Indo-Rama Synthetics Tbk. Divisi Spun Yarns?

2. Bagaimana pengaruh secara bersama-sama pelaksanaan kompensasi, pengembangan karir dan pelatihan sumber daya manusia terhadap kinerja karyawan pada PT. Indo-Rama Synthetics Tbk Divisi Spun Yarns?

\section{KAJIAN PUSTAKA DAN PEGEMBANGAN.}

Manajemen adalah pencapaian tujuan organisasi dengan cara yang efektif dan efisien melalui perencanaan, pengorganisasian, pengarahan dan pengendalian

sumber daya organisasi (Daft, 2007, hlm. 6). Selanjutnya Stoner \& Freeman (dalam Wibowo, 2010, hlm. 1-2) mengemukakan bahwa manajemen merupakan suatu proses menggunakan sumber daya organisasi untuk mencapai tujuan organisasi melalui fungsi planning dan decision making, organizing, leading dan controlling. Manajemen juga dikatakan sebagai suatu proses perencanaan, pengorganisasian, memimpin dan mengawasi pekerjaan anggota organisasi dan menggunakan semua sumber daya organisasi yang tersedia untuk mencapai tujuan organisasi yang dinyatakan dengan jelas.

Sejalan dengan penjabaran tersebut, maka manajemen sumber daya manusia (manajemen personalia) dapat diartikan sebagai perencanaan, pengorganisasian, pengaßahan, dan pengendalian atas tenaga kerja, pengembangan, kompensasi, integrasi, pemeliharaan dan pemutusan hubungan kerja dengan sumber daya manusia untuk mencapai sasaran perorangan, organisasi dan masyarakat (Flippo, 1984, hlm. viii). Dan bila dikaji dengan teliti, berdasarkan definisi tersebut terdapat dua fungsi yaitu 1) fungsi manajemen, yang meliputi perencanaan (planning), pengorganisasian (oranising), pengarahan (directing) dan pengendalian (controlling); serta 2) fungsi operasional, yang meliputi perekrutan dan seleksi, pelatihan dan pengembangan, kompensasi balas jasa dan jaminan social, pengembangan karir, integritas, pemeliharaan tenaga kerja dan pemutusan hubungan kerja.

Istilah kinerja sumber daya manusia berasal dari kata job performance atau actual performance, yaitu prestasi kerja atau prestasi sesungguhnya yang dicapai seseorang. Dan kinerja karyawan (prestasi kerja) merupakan hasil kerja secara kualitas dan kuantitas yang dicapai oleh seseorang karyawan dalam melaksanakan tugasnya sesuai dengan tanggung jawab yang diberikannya (Mangkunegara, 2005, hlm. 9).

Selanjutnya, kinerja individu menurut Mangkunegara (2005, hlm. 15) adalah hasil kerja karyawan baik dari segi kualitas maupun kuantitas berdasarkan standar kerja yang telah ditentukan. Kinerja individu akan tercapai apabila didukung oleh atribut individu, upaya kerja (work effort) dan dukungan organisasi.

Kinerja merupakan hasil pekerjaan yang mempunyai hubungan kuat dengan tujuan strategi organisasi, 
kepuasan konsumen dan memberikan kontribusi

ekonomi (Amstrong \& Baron dalam Wibowo, 2010, hlm. 7). Kinerja merupakan fungsi dari motivasi dan kemampuan untuk menyelesaikan tugas atau pekerjaan individu, dimana sepatutnya memiliki derajat kesediaan dan tingkat kemampuan tertentu. Kesediaan dan keterampilan individu tidaklah cukup efektif untuk mengerjakan sesuatu tanpa pemahaman yang jelas tentang apa yang akan dikerjakan dan bagaimana mengerjkannya. Kinerja merupakan perilaku nyata yang ditampilkan setiap individu sebagai prestasi kerja yang dihasilkan oleh karyawan sesuai dengan perannya dalam perusahaan. Kinerja karyawan merupakan suatu hal yang penting dalam upaya perusahaan untuk mencapai tujuannya Rivai( 2004, hlm. 56).

Menurut Dharma (2010, hlm. 96), terdapat garis-garis besar bagi penentuan ukuran kinerja, yaitu : 1) ukuran kinerja harus berhubungan dengan hasil yang dicapai, bukan usaha untuk mendapatkannya; 2) hasil kinerja harus berada di bawah kendali pemegang pekerjaan; 3) ukuran yang dipakai harus bersifat objektif dan dapat diamati; 4) data harus tersedia untuk pengukuran; 5) ukuran yang sudah ada harus dipakai atau dimanfaatkan bilamana mungkin.

Adapun penilaian kinerja menurut Rivai (2004, hlm. 87) mengacu pada suatu sistem formal dan terstruktur yang digunakan untuk mengukur, menilai dan mempengaruhi sifat-sifat yang berkaitan dengan pekerjaan, perilaku dan hasil, termasuk tingkat ketidakhadiran. Dalam prakteknya istilah penilaian kinerja performance appraisal) dan evaluasi kinerja (performance evaluation) dapat digunakan secara bergantian atau bersamaan karena pada dasarnya memiliki maksud yang sama.
Selanjutnya Aguinis (2009, hlm.78-79) menambahkan bahwa terdapat tiga faktor penting yang berhubungan dengan penilaian kinerja, antara lain : 1) declarative knowledge adalah pemahaman karyawan (berupa fakta, prinsip dan tujuan) terhadap tugastugas yang harus dilakukan dalam melaksanakan pekerjaan; 2) procedural knowledge adalah informasi dan kepakaran yang dibutuhkan keryawan untuk melakukan pekerjaan dengan tindakantindakan spesifik berupa ketrampilan kognitif, psikomotorik, fisik dan antar pribadi; serta 3) motivation adalah kemauan untuk memilih (pilihan untuk bertindak), tingkat upaya dan ketangguhan upaya.

Kompensasi merupakan motif utama seseorang dalam bekerja. Dengan kompensasi, seseorang berharap dapat memenuhi semua kebutuhannya mulai dari hierarki yang paling rendah sampai yang paling tinggi. Kompensasi merujuk pada semua bentuk hasil keuangan dan tunjangan nyata yang diterima pekerja sebagai bagian dari hubungan kerja (Bernardin, 2007, hlm. 252). Menurut Werther \& Davis (dalam Wibowo, 2010, hlm. 348) mendefinisikan kompensasi sebagai apa yang diterima pekerja sebagai tukaran atas kontribusinya kepada organisasi.

Sejalan dengan pemikiran tersebut, Stone (dalam Suwatno \& Priansa, 2011, hlm. 220) mengemukakan bahwa kompensasi adalah setiap bentuk pebayaran yang diberikan kepada karyawan sebagai pertukaran pekerjaan yang mereka berikan kepada majikannya.

Flippo dalam Suwatno \& Priansa (2011, hlm. 220) menyebutkan kompensasi merupakan pemberian imbalan jasa yang layak dan adil kepada karyawan karena telah memberikan sumbangan kepada pencapaian organisasi. Menurut Ivancevich (2001, hlm. 286), kompensasi merupakan 
segala bentuk penghargaan atau imbalan yang diberikan oleh perusahaan untuk penggantian atas kinerja karyawan yang terdiri atas kompensasi finansial langsung (seperti: gaji pokok, insentif dan bonus); kompensasi non finansial tidak langsung (seperti jaminan asuransi dan tunjangan lainnya); serta bentuk kompensasi non financial (seperti pekerjaan yang menarik minat, tantangan pekerjaan, tanggung jawab, pengakuan yang memadai atas prestasi yang dicapai dan adanya peluang promosi bagi karyawan yang berpotensi).

Kemudian Handoko (2008, hlm.

160) menambahkan bahwa dalam menetapkan kompensasi maka suatu organisasi harus memperhatikan prinsip keadilan yang dipengaruhi oleh dua faktor, yaitu : 1) ratio kompensasi dengan masukan (input) karyawan berupa tenaga, pendidikan, pengalaman, latihan, daya tahan dan sebagainya; serta 2) perbandingan ratio tersebut dengan ratio yang diterima orang lain dengan siapa kontak langsung selalu terjadi. Keadilan biasanya ada bila seorang karyawan memandang ratio penghasilan terhadap masukan adalah seimbang (equilibrium), baik secara internal maupun hubungannya dengan karyawan lain.

Karir adalah semua pekerjaan yang dijalani seseorang sepanjang kehidupan kerjanya. Karir adalah pola pengalaman yang berhubungan dengan pekerjaan dan aktivitas yang dilakukan seseorang dalam kehidupan kerjanya (Werther dan Davis, 1996, hlm. 311). Selanjutnya menurut Ivancevich (2001, hlm.429), karir adalah pola peningkatan dalam pekerjaan sepanjang waktu kehidupan kerja seseorang, mencakup tahapan karir dan setiap tahapan terkait dengan usia dan kebutuhan pribadi.

Greenhaus (dalam Ivancevich, 2001, hlm. 428), karir adalah pola pengalaman yang berhubungan dengan pekerjaan (posisi jabatan, tugas pekerjaan, keputusan-keputusan dan interpretasi subjektif terhadap situasi pekerjaan) dan aktivitas yang dilakukan dalam kehidupan kerjanya. Sedangkan Dessler (1997, hlm. 46) mengemukakan bahwa karir adalah serangkaian posisi yang berhubungan dengan kerja, entah dibayar atau tidak, yang membantu seseorang bertumbuh dalam keterampilan, keberhasilan, dan pemenuhan kerja. Menurut Mathindas (1997, hlm. 111) mengemukakan bahwa karir adalah suatu kemajuan seseorang dalam profesi atau pilihan bidang pekerjaan tertentu, dimana kemajuan yang dimaksud adalah peningkatan keberadaan subjek di dalam sebuah organisasi yang bergerak pada jenis atau pilihan usaha tertentu.

Salah satu fungsi penting dalam manajemen karir adalah membuat perencanaan karir. Perencanaan karir adalah perencanaan yang dilakukan oleh individu atau oleh organisasi berkenaan dengan karir karyawan, terutama melalui persiapan yang harus dipenuhi seorang karyawan untuk mencapai tujuan karir tertentu. Mengingat pada umumnya para karyawan menginginkan adanya promosi, maka dalam suatu organisasi perlu dibuat suatu program perencanaan karir yang jelas dimana jalur karir yang harus ditempuh menjadi pasti (Irawan, 1997: 158).

Menurut Dessler (197, hlm. 46), perencanaan karir adalah proses pertimbangan mendalam yang melaluinya seseorang menjadi sadar akan keterampilan, minat, pengetahuan, motivasi, karakteristik personil lainnya. Sedangkan Simamora (2004, hlm. 504) mengungkapkan bahwa perencanaan karir adalah proses yang dilalui oleh karyawan dalam mengidentifikasi dan mengambil langkah-langkah untuk mencapai tujuantujuan karirnya dengan mengevaluasi kemampuan dan minatnya sendiri, mempertimbangkan kesempatan karir lternative, menyusun tujuan karir dan 
merencanakan aktivitas pengembangan praktis.

Salah satu kebutuhan karyawan dalam bekerja adalah adanya pengembangan karir yang diatur dalam suatu jalur karir dalam organisasi. Dalam hal ini jalur karir adalah pola urutan pekerjaan (pattern of work sequence) yang harus dilalui karyawan untuk mencapai suatu tujuan akhir. Jalur karir selalu bersifat formal dan ditentukan oleh organisasi. Seperti di lingkungan karyawan negeri sipil yang dikenal dengan jalur structural dan jalur fungsional (Irawan, 1997, hlm. 157).

Jalur karir dalam organisasi menurut Simamora (2001, hlm. 252) paling tidak haruslah memiliki 4 (empat) karakteristik, antara lain : 1) jalur karir haruslah mewakili kemungkinan kemajuan riel, baik secara lateral maupun ke bawah; 2) jalur karir haruslah merespon perubahan-perubahan dalam beban kerja, prioritas kerja, struktur organisasional dan kebutuhan manajemen; 3) jalur karir haruslah uwes serta mempertimbangkan kualitas individu, manajer, bawahan atau orang lain yang mempengaruhi cara kerja dilaksanakan; serta 4) jalur karir haruslah menentukan keahlian, pengetahuan dan atribut spesifik lainnya yang dapat diperoleh guna melaksanakan pekerjaan pada setiap posisi sepanjang jalur yang ada.

Jalur karir dalam pengembangan sumber daya manusia merupakan dasar untuk menentukan pengembangan karir karyawan. Pengembangan karir dalam organisasi (pemerintah maupun swasta) merupakan bagian dari pengelolaan sumber daya manusia yang bertujuan untuk memajukan dan menguntungkan organisasi. Pengelolaan sumber daya manusia dalam organisasi pemerintahan sebagaimana termuat dalam UndangUndang nomor 43 tahun 1999 pasal 12 ayat (2) tentang Pokok-Pokok Kekaryawanan menyebutkan bahwa pembinaan merupakan bagian dari manajemen karyawan negeri sipil. Dalam melaksanakan pembinaan di lingkungan karyawan negeri sipil, didasarkan "sistem prestasi kerja dan sistem karir" yang dititik beratkan pada prestasi kerja. Dalam konteks kebijakan manajemen karyawan negeri sipil, kedua sistem tersebut harus menjadi landasan dalam pengembangan karir karyawan negeri sipil. Pada tingkat pelaksanaan kedua sistem tersebut akan tercermin dalam persyaratan-persyaratan, misalnya persyaratan untuk pengangkatan dalam suatu jabatan, promosi, mutasi dan sebagainya.

Hipotesis menurut Kerlinger (2006:30) adalah pernyataan dugaan (2006: 30) adalah pernyataan dugaan (conjectural) mengenai hubungan atau relasi antara dua variael atau lebih. Hipotesis selalu mengambil bentuk kalimat pernyataan (declarative) dan menghubungkan secara umum maupun khusus variable yang satu dengan variable yang lain. Hipotesis dalam penelitian ini dirumuskan sebagai berikut:

1. Ho : Tidak terdapat pengaruh kompensasi/imbalan yang signifikan dan positif terhadap kinerja karyawan di PT. Indo-Rama Synthetics Tbk. Divisi Spun Yarns.

$\mathrm{Ha}$ : Terdapat pengaruh kompensasi/imbalan yang signifikan dan positif terhadap kinerja karyawan di PT. Indo-Rama Synthetics Tbk. Divisi Spun Yarns.

2. Ho : Tidak terdapat pengaruh pengembangan karir yang signifikan dan positif terhadap kinerja karyawan di PT. Indo-Rama Synthetics Tbk. Divisi Spun Yarns.

$\mathrm{Ha}$ : Terdapat pengaruh pengembangan karir yang signifikan dan positif terhadap kinerja karyawan di PT. Indo-Rama Synthetics Tbk. Divisi Spun Yarns. 
3. Ho : Tidak terdapat pengaruh pelatihan yang signifikan dan positif terhadap kinerja karyawan di PT. Indo-Rama Synthetics Tbk. Divisi Spun Yarns.

$\mathrm{Ha}$ : Terdapat pengaruh pelatihan yang signifikan dan positif terhadap kinerja karyawan di PT. Indo-Rama Synthetics Tbk. Divisi Spun Yarns.

2. Ho : Tidak terdapat pengaruh kompensasi, karir dan pelatihan yang signifikan dan positif terhadap kinerja karyawan di PT. Indo-Rama Synthetics Tbk. Divisi Spun Yarns.

Ha : Terdapat pengaruh kompensasi, karir dan pelatihan yang signifikan dan positif terhadap kinerja karyawan di PT. Indo-Rama Synthetics Tbk. Divisi Spun Yarns.

\section{METODE PENELITIAN}

Objek penulisan merupakan sasaran untuk mendapatkan suatu data, Husein Umar (2005, Hlm. 303), mendefinisikan objek penulisan sebagai berikut: "Objek penulisan menjelaskan tentang apa dan siapa yang menjadi objek penulisan. Juga dimana dan kapan penulisan dilakukan. Bisa juga ditambahkan hal-hal lain jika dianggap perlu".

Objek penulisan yang diteliti adalah Pengaruh praktik manajemen terhadap kinerja karyawan. Penulisan ini dilaksanakan di sebuah perusahaan textile bernama PT. Indo-Rama synthetics Tbk Divisi Spun Yarns yang berlokasi di Desa Kembang Kuning Ubrug Jatiluhur Purwakarta. Waktu penelitaian selama 3 bulan mulai bulan Maret s/d bulan Juni 2015.

Jumlah Partisipan yang terlibat pada penulisan ini sebanyak 1682 (seribu enam ratus delapan puluh dua) orang, dengan karakteristisk partisipan dikelompoklan berdasarkan pendidikan, level/jabatan, Usia, Masa kerja dan Departemen.
Adapun populasi dalam penelitian ini adalah keseluruhan individu anggota populasi relatif memiliki sifat-sifat individual, di mana sifat tersebut membedakan individu anggota populasi yang satu dengan yang lainnya. Dengan kata lain bahwa individu anggota populasi memiliki sifat yang bervariasi sehingga memerlukan penjelasan terhadap sifat-sifat tersebut baik secara kuantitatif maupun kualitatif.

Dari jumlah populasi tersebut penulis menggunakan tingkat kelonggaran ketidaktelitian sebesar $10 \%$,

Dengan menggunakan rumus tersebut diatas diperoleh sampel sebesar :

$$
\mathbf{n}=\frac{1682}{1+1682(0.10)^{2}}=\frac{1682}{23.15}=94.39
$$

Maka sampel yang digunakan dibulatkan menjadi 94 orang. Rincian jumlah sampel dari kelompok departemen sebanyak 94 orang.

Pengumpulan data dilakukan dengan metode survey menggunakan kuesioner atau angket, yaitu serangkaian atau daftar pertanyaan yang disusun secara sistematis, kemudian dikirim untuk diisi oleh responden dan setelah diisi, angket dikembalikan kepada peneliti. Penggunaan angket atau kusesioner dalam penelitian ini adalah untuk memperoleh data yang akurat. Dimensi-dimensi indikator sebagai instrumen penelitian dituangkan ke dalam kuesioner yang dipergunakan dalam penelitian Tipe pertanyaan yang digunakan dalam kuesioner tersebut adalah pertanyaan tertutup dan sifat data yang diperoleh dari kusesioner berupa data interval. Dalam data interval, setiap item instrument yang menggunakan skala ordinal mempunyai jawaban dengan gradasi dari sangat setuju sampai sangat tidak setuju, dimana tiap jawaban dapat diberi skor. Perhitungan skor nilai jawaban responden 
berdasarkan nilai rata-rata seluruh responden terhadap pertanyaan.

Analisis statistik inferensial digunakan untuk mengolah dan mengorganisasikan data serta merumuskan hasil yang dapat diinterpretasikan dengan mencari nilainilai secara terperinci tentang rata-rata hitung (mean), nilai tengah, mode, simpangan (standar deviasi), interval, nilai maksimum dan nilai minimum dari masing-masing variabel yang diuji dalam penelitian. Disamping itu, analisis ini juga dipakai untuk mengukur dan menguji hubungan serta pengaruh antara variabel bebas dengan variabel terikat. Untuk mengukur seberapa besar pengaruh antara variabel bebas (independent) terhadap variabel terikat (dependent), maka dilakukan dengan analisis regresi.

Kerangka berpikir yang baik akan menjelaskan secara teoritis pertautan antar variabel yang akan diteliti. Jadi secara teoritis perlu dijelaskan hubungan antara variabel independen dan dependen, bila dalam penelitian ada variabel moderator dan intervening, maka juga perlu dijelaskan, mengapa variabel itu diikutkan. Pertautan antar variabel tersebut selanjutnya dirumuskan kedalam bentuk paradigma penelitian yang didasarkan pada kerangka berpikir.

Pada gambar di bawah ini dijelaskan bahwa praktik sumber daya manusia yang diteliti adalah Kompensasi, karir dan pelatihan dan pengaruhnya dari ketiga praktik sumber daya manusia tersebut terhadap kinerja karyawan.

Hasil uji segrespesparsi ar ariabel X berpengaruh terhadap variab $1 \mathrm{Y}$ apabila

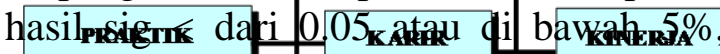

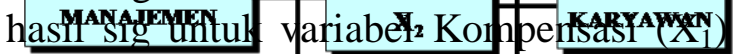
adalah 0.078 atau $78 \%$. Hassil sig untuk variabel Variabet Raris $27,2 \%$ dan hasil sis untuk variabel pelatihan $\left(\mathrm{X}_{3}\right) 0.000$, Jadi hanya variabel $\left(\mathrm{X}_{3}\right)$ yang memiliki sig $<0.05$, dengan

\section{HASIL DAN PEMBAHASAN}

PT. Indo-Rama Synthetics Tbk. didirikan pada tahun 1974, memulai memproduksi pada tahun 1976 dengan sebuah pabrik pemintalan kapas di Purwakarta yang terus melakukan diversifikasi dan memperluas bisnis pemintalannya dan menambahkan pembuatan Polyester Filament Benang, Polyester Staple Fibre, PET Resin, Polyester Chips, dan Polyester Filament Kain untuk pasar global serta pabrikpabrik ini berlokasi di Jawa Barat (di Purwakarta, Campaka dan Bandung), Indonesia dan Uzbekistan (melalui anak perusahaan). Perusahaan telah terdaftar di Bursa Efek Indonesia sejak tahun 1990. (Indo-Rama Profile, 2013).

Indonesia merupakan salah satu kawasan yang memiliki pengaruh signifikan terhadap perkembangan ekonomi global. Dan pada tahun ini, pertumbuhan ekonomi Indonesia menunjukkan pengaruh yang kuat terhadap perkembangan ekonomi dunia. Didorong dengan biaya produksi yang kompetitf di tanah air dibandingkan dengan biaya di kawasan lainnya, kami berinisiatif untuk terus memanfaatkan keunggulan biaya kompetitif guna memasuki pasar baru dengan produk yang berbeda. (Indo-Rama Profile, 2013).

demikian, hanya variable pelatihan $\left(\mathrm{X}_{3}\right)$ yang berpengaruh terhada $\mathrm{Y}$.

Selanjutnyadengan memandingkan $\mathrm{t}$ hitung dan $\mathrm{t}$ tabel. Signifikn apabila $\mathrm{t}$ hitung $>$ dari $t$ tabel. Hasil pengujian menunjukkan bahawa t hitung untuk $\left(\mathrm{X}_{1}\right)$ adalah 1.786 dan untuk $\left(\mathrm{X}_{2}\right)$ adalah 0.05 atau $5 \%$ (jumlah data 94 dikurangi 3 variabel bebas). Jadi hanya variable $\left(\mathrm{X}_{3}\right)$ yang memiliki $t$ hitung lebih besar dari $t$ 
table. Dengan demikian hanya variable pelatihan $\left(\mathrm{X}_{3}\right)$ yang berpengaruh terhadap kinerja karyawan (Y).

Dari output SPSS diperoleh nilai yang diinginkan pada kolom Pearson Correlation diperoleh nilai $\mathrm{r}$ : $\mathrm{X}_{1}$ terhadap $\mathrm{Y}=0.440$ atau $\mathrm{r}_{\text {hitung }}(0.440)>\mathrm{r}_{\text {tabel }}$ (0.2028) jadi Ho ditolak, artinya terdapat hubungan positif yang cukup kuat antara kompensasi terhadap kinerja karyawan, hal ini karena koefisien korelasi $>r_{\text {tabel }}$ maka ada korelasi yang signifikan (Ha diterima).

Besarnya sumbangan (kontribusi) $\mathrm{X}_{1}$ dengan $\mathrm{Y}$ sebesar $44 \%$, artinya artinya terdapat hubungan positif yang cukup kuat antara pelatihan terhadap kinerja karyawan, hal ini karena koefisien korelasi $>r_{\text {tabel }}$ maka ada korelasi yang signifikan (Ha diterima). Besarnya sumbangan (kontribusi) $\mathrm{X}_{2}$ dengan $\mathrm{X}_{3}$ . Dari hasil output SPSS diperoleh $\mathrm{R}$ $=0.648$, dengan $R^{2}=0.420$. Nilai $R$ merupakan hubungan antara kompensasi, karir dan pelatihan. Untuk mengetahui seberapa besar kualitas model regresi linier berganda yang terbentuk, perhatikan nilai koefisien determinasi $(\mathrm{R}$ square $)=0.420$.

\section{KESIMPULAN}

Penelitian ini dilakukan sebagai usaha untuk melihat pengaruh praktik manajemen diantaranya kompensasi, karir dan pelatihan baik secara parsial maupun secara simultan terhadap kinerja karyawan. Penelitian ini memberikan bukti bahwa aplikasi penerapan praktik manajemen, melalui kompensasi, karir dan pelatihan akan berpengaruh pada kinerja karyawan. Semakin baik penerapan program kompensasi, karir dan pelatihan maka semakin tinggi pula kinerja karyawan yang ditunjukkan.

\section{Berdasarkan}

standardized regression weight dapat diketahui bahwa variable pelaatihan merupakan variable yang paling berpengaruh dalam meningkatkan kinerja karyawan. Variable $\mathrm{k}$ arirmerupaan variable yang paling rendah pengaruhnya terhadap kinerja karyawan. Hal ini berarti variable
Kompensasi memberikan kontribusi terhadap kinerja karyawan sebesar $44 \%$ dan sisanya $56 \%$ ditentukan oleh variabel lain. Terbukti adanya hubungan yang signifikan antara $\mathrm{X}_{1}$ dan $\mathrm{Y}$. Pada descriftive statistic, output tersebut dapat dilihat nilai rata-rata kompensasi dari 94 karyawan adalah 28.00 dengan standar deviasi 3.767.

Dari output SPSS diperoleh nilai yang diinginkan pada kolom Pearson Correlation diperoleh nilai $\mathrm{r}: \mathrm{X}_{2}$ terhadap $\mathrm{X}_{3}=0.412$ atau $\mathrm{r}_{\text {hitung }}(0.412)>\mathrm{r}_{\text {tabel }}$ (0.2028) jadi Ho ditolak, sebesar 41.2\%, artinya pelatihan memberikan kontribusi terhadap kinerja karyawan sebesar $41.2 \%$ dan sisanya $58.8 \%$ ditentukan oleh variabel lain. Terbukti adanya hubungan yang signifikan $\begin{array}{llll}\text { antara } & \mathrm{X}_{2} & \text { dan } & \mathrm{X}_{3} \text {. }\end{array}$ Nilai tersebut menunjukkan informasi bahwa $42 \%$ nilai dari besarnya kompensasi, karir dan pelatihan. Sisanya $58 \%$ merupakan kontribusi dari faktor-faktor lain selain faktor yang diwakili oleh variabel bebas.

pelatihan sangat mempengaruhi kinerja karyawan, maka yang harus diperhatikan adalah memberikan pelatihan secara kontinyu kepada karyawan

Dari hasil penelitian maka penulis dapat menyampaikan saran-saran sebagai berikut:

1. Dari hasil analisis pengaruh praktik manajemen terhadap kinerja karyawan, variable karir memiliki tingkat kesesuaian yang paling rendah dibanding ketiga variabel lainnya maka disarankan agar program pengembangan karir dapat diterapkan dengan baik.

2. Saran untuk penelitian mendatang, agar penelitian yang berkaitan dengan Sumber Daya Manusia dapat dikembangkan menjadi Human Capital, karena Human Capital merupakan sistem manajemen yang 
terupdate.

\section{DAFTAR PUSTAKA}

Aguinis, Herman. (2009). "Performance Management" Second Edition. New Jersey : Pearson International Edition.

Armstrong, Michael. (1994). "Performance Management". Kogan Page Limited.

Armstrong, Michael. (1998). "Manajemen Sumber Daya Manusia" Terjemahan. Jakarta : PT. Gramedia Pustaka Utama.

As'ad, M. (1991). "Psikologi Industri”. Yogyakarta : Liberty.

Bernardin, John. (2007). "Human Resource Management". New York : McGraw-Hill Irwin.

Bungin, Burhan. (2010). "Metodologi Penelitian Kuantitatif". Jakarta : Kencana Prenada Media Group.

Daft, Richard L. (2007). "Management" (Terjemahan) Edisi Enam Buku Satu. Jakarta : Penerbit Salemba Empat.

Dessler, Gary.

"Manajemen Sumber Daya Manusia" (Terjemahan).Florida : Prentice Hall.

Dessler, Gary. (2003)

"Manajemen Sumber Daya Manusia"

Edisi kesembilan. Jakarta : Index Kelompok Gramedia.

Dharma, Surya. (2010).

"Manajemen Kinerja". Yogyakarta :

Penerbit Pustaka Pelajar.

Flippo, Edwin B. (1984). "Manajemen Personalia" Jilid I. Terjemahan Moh. Masud. Jakarta : PT. Gelora Aksara Pratama.

George, Jennifer M. \& Jones, Gareth R. (1999). "Organizational Behavior" $2^{\text {nd }}$ Edition. USA : Addison Wesley Publishing Company.

Gibson, Donnelly \& Ivancevich. (1997). "Manajemen" Edisi 9. Jakarta : Erlangga Comes, Faustino Cardoso.
(2003). "Manajemen Sumber Daya Manusia". Yogyakarta : Penerbit Andi.

Gouzali, Saydam.

(1996).

"Manajemen Sumber Daya Manusia, Human Resources Management" Jilid 2. Jakarta : Gunung Agung.

Handoko, T. Hani. (2003). "Manajemen" Edisi Dua. Yogyakarta : BPFE-Yogyakarta.

Handoko, T. Hani. (2008). "Manajemen Personalia dan Sumber Daya Manusia" Edisi Dua. Yogyakarta : Penerbit BPFE.

Hasibuan, Malayu SP. (1990). "Manajemen Sumber Daya Manusia: Dasar Kunci Keberhasilan". Jakarta : Haji Mas Agung.

ICOM. (2004). "Running a Museum : A Practical Handbook". France : ICOM -International Council of Museums.

Irawan, Prasetya., Motik, Suryani. \& Sakti, Sri Wahyu Krida. (1997)."Manajemen Sumber Daya Manusia". Jakarta : STIA-LAN Press.

Ivancevich, John M. (2001). “ Human Resource Management" $8^{\text {th }}$ Edition. USA, Richard D. Irwin, Inc.

Kerlinger,Fred N.(2006). "AsasAsas Penelitian Behavioral".Yogyakarta :Gadjah Mada University Press.

Kewell \& Siegall, M. (1990). "Psikologi Industri/Organisasi Modern". Jakarta : Arcan.

Mangkunegara, A.A, Anwar Prabu. (2005). "Evaluasi Kinerja SDM". Bandung : PT. Refika Aditama.

Mathindas, R. (1997). "Manajemen Sumber Daya Manusia Konsep AKU. Pustaka Utama Jakarta : Grafiti.

Milkovich, George T. \& Newman Jerry M. (2002). "Compensation" $7^{\text {th }}$ Edition, New York: McGraw-Hill.

Mondy, R. Wayne., Noe, Robert M. \& Premeaux, Shane R. (2002). 
"Human Resource Management" $8^{\text {th }}$ Edition. New Jersey : Prentice Hall.

Munandar, Ashar Sunyoto. (2001).

"Psikologi Industri dan Organisasi". Jakarta : Penerbit Universitas Indonesia (UI-Press).

Nawawi, H Hadari. (2000).

"Manajemen SDM" Cetakan Ke-3.

Yogyakarta : Gamma.

Rao, T.V., (1996). "PPenilaian

Kerja Teori dan Praktek". Jakarta :

Pustaka Binaman Pressindo, PT.

Rivai, Veithzal. (2004).

"Manajemen Sumber Manusia

Perusahaan". Jakarta : Murai Kencana.

Robbins, Stephen P. (2001).

"Organizational Behavior: Concepts,

Controversies Application" Jilid 1 dan 2

(Terjemahan). Jakarta : Prenhallindo.

Robbins, Stephen P. \& Coulter,

Mary. (2007). "Manajemen

(Terjemahan)" Edisi Kedelapan Jilid Satu.

Jakarta : PT. Indeks.

Robbins, Stephen P. \& Judge,

Timothy A. (2008). "Perilaku

Organisasi (Terjemahan)" Edisi

Keduabelas Buku Dua. Jakarta : Salemba

Empat.

Schuler, Randall S., \& Jackson, Susan E. (1999). "Human Resourse Management: Positioning for the 21th Century (Manajemen Sumber Daya Manusia: Menghadapi Abad ke-21). Jakarta : Erlangga.

Siagian, Sondang P. (2010). "Manajemen Sumber Daya Manusia". Jakarta : Bumi Aksara.
Simamora, Henry.(2004). "Manajemen Sumber Daya Manusia" Edisi III. Yogyakarta : Bagian Penerbitan SITE YKPN.

Spencer, Lyle M. Jr., dan Spencer, Signe M. (1993). "Competence at Work Models for Superior Performance”. USA : John Wiley \& Sons, Inc.

Sutaarga, Moh. Amir. (1983). "Pedoman Penyelenggaraan dan Pengelolaan Museum" Cetakan Kedua. Jakarta : Direktorat Permuseuman Direktorat Jenderal Kebudayaan Departemen Pendidikan dan Kebudayaan. Sutrisno, Edy. (2009). "Manajemen Sumber Daya Manusia". Jakarta : Kencana Prenada Media Group.

Suwatno, H. \& Priansa, Donni Juni. (2011). "Manajemen SDM dalam Organisasi Publik dan Bisnis". Bandung : Alfabeta.

Umam, Khaerul. (2010). "Perilaku Organisasi”. Bandung : CV. Pustaka Setia. Werther, William B., dan Davis, Keith. (1996). "Human Resources and Personal Management" $5^{\text {th }}$ Edition. McGraw-Hill, Inc.

Wibowo. (2010). "Manajemen Kinerja" (Edisi Ketiga). Jakarta : PT. Rajawali Pers.

Yamin, Sofyan. \& Kurniawan, Heri. (2009). "SPSS Complete : Teknik Analisis Statistik Terlengkap dengan Software SPSS". Jakarta : Penerbit Salemba Infotek. 